\title{
Global mechanical properties of trabecular bone : experimental determination and prediction from a structural model
}

\author{
Citation for published version (APA): \\ Campen, van, D. H., Klever, F. J., Klumpert, R., Horenberg, J., Grootenboer, H. J., \& Pauly, T. (1985). Global \\ mechanical properties of trabecular bone : experimental determination and prediction from a structural model. In \\ S. M. Perren, \& E. Schneider (Eds.), Biomechanics : current interdisciplinary research : selected proceedings of \\ the fourth meeting of the European Society of Biomechanics in collaboration with the Society of Biomaterials, \\ September 24-26, 1984, Davos, Switzerland (pp. 167-172). Nijhoff.
}

\section{Document status and date:}

Published: 01/01/1985

\section{Document Version:}

Publisher's PDF, also known as Version of Record (includes final page, issue and volume numbers)

\section{Please check the document version of this publication:}

- A submitted manuscript is the version of the article upon submission and before peer-review. There can be important differences between the submitted version and the official published version of record. People interested in the research are advised to contact the author for the final version of the publication, or visit the $\mathrm{DOI}$ to the publisher's website.

- The final author version and the galley proof are versions of the publication after peer review.

- The final published version features the final layout of the paper including the volume, issue and page numbers.

Link to publication

\footnotetext{
General rights

- You may freely distribute the URL identifying the publication in the public portal. follow below link for the End User Agreement:

www.tue.nl/taverne

\section{Take down policy}

If you believe that this document breaches copyright please contact us at:

openaccess@tue.nl

providing details and we will investigate your claim.
}

Copyright and moral rights for the publications made accessible in the public portal are retained by the authors and/or other copyright owners and it is a condition of accessing publications that users recognise and abide by the legal requirements associated with these rights.

- Users may download and print one copy of any publication from the public portal for the purpose of private study or research.

- You may not further distribute the material or use it for any profit-making activity or commercial gain

If the publication is distributed under the terms of Article 25fa of the Dutch Copyright Act, indicated by the "Taverne" license above, please 
19. GLOBAL MECHANICAL PROPERTIES OF TRABECULAR BONE: EXPERIMENTAL DETERMINATION AND PREDICTION FROM A STRUCTURAL MODEL

\author{
I \\ F.J. Klever, R. Klumpert, J.Horenberg, H.J. Grootenboer, \\ D.H. Van Campen and T. Pauly
}

Twente University of Technology, Enschede, The Netherlands

\title{
1. INTRODUCTION
}

Trabecular bone is a porous material composed of rods and plates of bone tissue. The orientation of these trabeculae accounts for the anisotropic mechanical behaviour of the material. This behaviour further depends on the location in the bone since, shape, dimensions and orientation of the trabeculae are not constant. In order to gain more insight in the mechanical behaviour of trabecular bone, both a method for the experimental determination of material properties and a structural model have been developed.

\section{EXPERIMENTAL INVESTIGATION}

The mechanical properties were measured on 27 cubic samples of fresh trabecular bone with marrow in situ. These specimens were taken from the proximal epiphysis of a human tibia. Figure 1 shows the location of the samples. On a Reichert-Jung microtome with milling attatchment the surfaces were milled until the sides of the specimen measured $8 \mathrm{~mm}$. This procedure ensures smooth and plane surfaces without damage being done to the trabecular structure. The specimens were compressed between two parallel plates in a specially designed loading device. The force on the movable plate was measured with a load cell and the displacement of that plate was measured with a displacement transducer (LVDT). Both signals were combined to a load/displacement curve on an $x-y$ recorder. From the slope of this curve and the

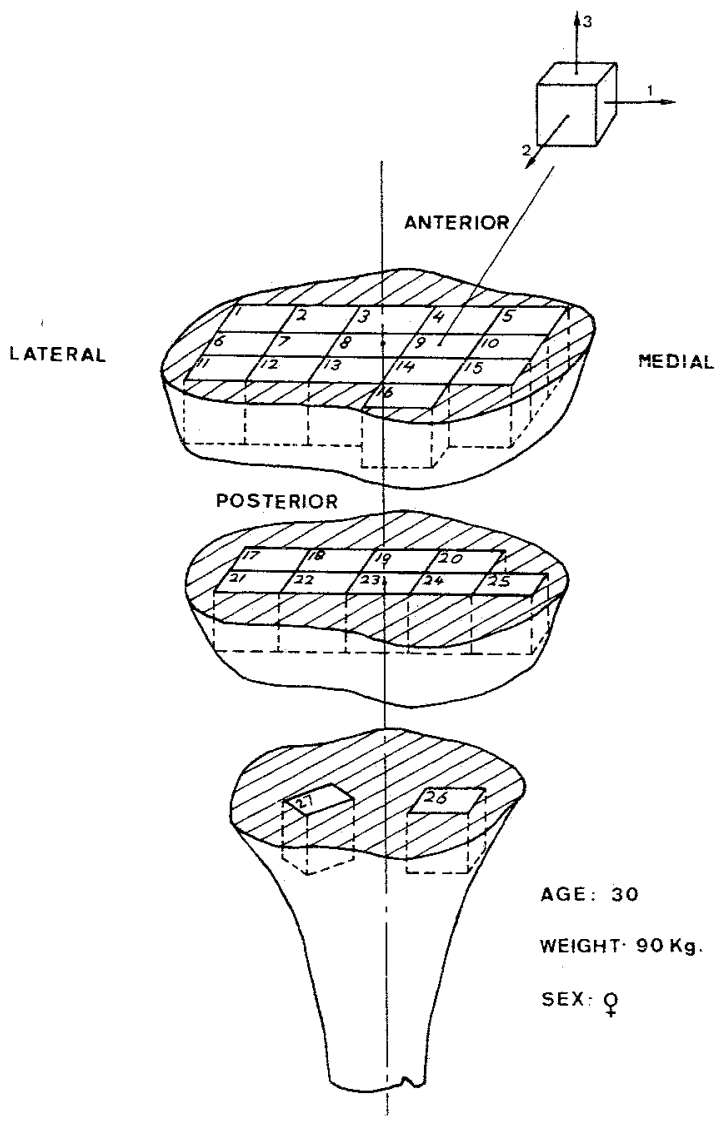

FIGURE 1: Location of the bone samples with global coordinate directions

dimensions of the specimen Young's modulus was determined. Young's moduli in the two other orthogonal directions were found by repeating this procedure two times with other sides of the sample facing the plates. 
During loading, the sideward expansion of the sample in the two directions perpendicular to the loading direction was determined. This was accomplished by measuring the displacement of two small mirrors bonded to opposite sides of the cube with laserinterferometers. The sideward expansion in the remaining direction was determined by repeating the compression test with the mirrors placed on the other free sides. The output signals of the interferometers were recorded together with the signals of the displacement transducer and the load cell on a four line $x-t$ recorder. Per sample six Poisson's ratios were calculated from the deformation results.

The ultimate compressive strength of the cancellous bone in proximal-distal direction was determined in a MTS testing machine. The samples were compressed with a constant strain rate of 0.01 per second. After determination of the ultimate strength the marrow was extracted from the specimens in order to perform density measurements like the apparent density and the density of the trabecular material. This was still possible, because in most cases the deformation had not exeeded $5 \%$. The methods used to determine the densities were those described by Carter and Hayes (1976).

\section{RESULTS AND DISCUSSION}

The results are listed in table 1 . The dimensions of the Young's moduli $E_{1}$ and the strength $\sigma_{c}$ are MPa, the densities $\rho_{a}$ and $\rho_{b}$ are given in $\mathrm{g} / \mathrm{cm}^{3}$.

3.1 Young's moduli

The load/displacement curves appeared to be almost linear except for the first part. All samples were loaded twice in each direction. In a few cases an increase in the slope up to $5 \%$ occurred at a second loading cycle. Subsequent loading had no effect on the stiffness. The moduli were determined from the slope of the linear part of the curve at the second loading cycle. The highest valuês for the E-moduli were found near the cortical shell, especially near the medial and lateral sides of the tibial plateau. This spatial variation of the stiffness is similar to that reported by Goldstein et. a1. (1983). All specimens showed a larger stiffness in proximal-distal direction than in the two other directions. This anisotropy became stronger with increasing distance from the tibial plateau, while at the same time the proximal-distal stiffness remained almost constant. The mean value for $E_{3}$ appeared to be about two times as large as the mean values for $\mathrm{E}_{1}$ and $\mathrm{E}_{2}$.

\subsection{Poisson's ratios}

The values for the Poisson's ratios ranged from 0.07-0.65. It appeared that $v_{31}$ and $v_{32}$ were considerably lower than the four other ratios. ( $v_{i j}$ relates the strain in $i-$ direction with the stress in j-direction). Generally the obtained values were much higher than those reported by Knauss (1981) for trabecular bone from the proximal part of the femur $(0.01-0.34)$.

\subsection{Compressive strength}

The magnitude of the compressive strength in proximal-distal direction ranged from 3-17 $\mathrm{MPa}$, consistent with previously published data (Goldstein et. a1., 1983; Carter and 
Hayes, 1977). There existed a strong correlation between the compressive strength and the elastic modulus in the same direction.

\begin{tabular}{|c|c|c|c|c|c|c|c|c|c|c|c|c|}
\hline SAMPLE & $E_{1}$ & $\mathbf{E}_{2}$ & $E_{3}$ & $\nu_{12}$ & $v_{13}$ & 21 & $\nu_{23}$ & $v_{31}$ & $v_{32}$ & $\sigma_{c}$ & $\rho_{a}$ & $P_{b}$ \\
\hline 1 & 918 & 617 & 952 & 0.37 & 0.24 & 0.56 & - & 0.20 & 0.24 & - & - & - \\
\hline 2 & 952 & 460 & 990 & 0.27 & 0.33 & 0.41 & 0.41 & 0.18 & 0.25 & 8.7 & 0.39 & 1.97 \\
\hline 3 & 580 & 203 & 741. & 0.24 & 0.29 & 0.40 & 0.44 & 0.25 & - & 6.0 & 0.33 & 1.97 \\
\hline 4 & 793 & 441 & 1043 & 0.33 & 0.35 & 0.45 & 0.44 & 0.18 & 0.21 & 14.7 & - & - \\
\hline 5 & 790 & 774 & 1667 & 0.46 & 0.30 & 0.45 & 0.32 & 0.17 & 0.21 & 17.0 & 0.58 & 1.96 \\
\hline 6 & 693 & 817 & 1134 & 0.57 & 0.52 & 0.38 & 0.37 & 0.17 & 0.20 & 10.6 & 0.47 & 1.95 \\
\hline 7 & 276 & 357 & 711 & 0.51 & 0.42 & 0.47 & 0.47 & 0.24 & 0.25 & - & 0.34 & 1.85 \\
\hline 8 & 187 & 317 & 349 & 0.45 & 0.50 & 0.28 & 0.42 & 0.37 & 0.36 & 3.4 & 0.25 & 1.98 \\
\hline 9 & 234 & 437 & 899 & 0.64 & 0.55 & 0.39 & 0.41 & 0.12 & 0.24 & - & 0.35 & 1.96 \\
\hline 10 & 989 & 957 & 1388 & 0.22 & 0.26 & 0.42 & 0.27 & 0.23 & 0.07 & 15.2 & - & - \\
\hline 11 & 685 & 566 & 1175 & 0.50 & 0.38 & 0.42 & 0.32 & 0.19 & 0.27 & 11.9 & 0.50 & 1.94 \\
\hline 12 & 462 & 427 & 1015 & 0.37 & 0.25 & 0.38 & 0.25 & 0.13 & 0.17 & 7.9 & 0.39 & 1.94 \\
\hline 13 & 150 & 291 & 504 & 0.42 & 0.46 & - & 0.49 & - & - & - & 0.27 & 1.85 \\
\hline 14 & 170 & 224 & 569 & 0.45 & 0.38 & 0.43 & 0.39 & 0.14 & 0.16 & - & 0.31 & 1.98 \\
\hline 15 & 458 & 509 & 1134 & 0.51 & 0.36 & 0.41 & 0.23 & 0.16 & 0.18 & - & 0.42 & 1.94 \\
\hline 16 & 625 & 345 & 765 & 0.32 & 0.27 & 0.53 & 0.49 & 0.18 & 0.21 & 6.8 & 0.37 & 1.97 \\
\hline 17 & 614 & 7.14 & 838 & 0.38 & 0.30 & 0.27 & - & - & - & 8.8 & 0.46 & 1.95 \\
\hline 18 & - & - & 987 & - & - & - & 0.28 & 0.13 & - & 8.6 & 0.35 & 1.99 \\
\hline 19 & 175 & 310 & 1140 & 0.43 & 0.63 & 0.30 & 0.41 & 0.13 & 0.15 & 9.8 & 0.34 & 1.96 \\
\hline 20 & 338 & 327 & 1449 & 0.51 & 0.44 & 0.44 & 0.39 & 0.20 & 0.12 & 11.5 & 0.42 & 1.97 \\
\hline 21 & 270 & 425 & 1273 & 0.45 & 0.60 & 0.34 & 0.48 & - & 0.21 & 10.8 & 0.38 & 2.00 \\
\hline 22 & 95 & 132 & 748 & 0.25 & 0.59 & - & 0.46 & 0.18 & 0.13 & 5.2 & 0.26 & 1.97 \\
\hline 23 & 64 & 191 & 293 & 0.50 & 0.60 & 0.26 & 0.38 & - & 0.28 & 3.0 & 0.22 & 1.90 \\
\hline 24 & 11 & 161 & 766 & 0.64 & 0.65 & - & 0.33 & 0.16 & - & - & 0.29 & 2.01 \\
\hline 25 & 342 & 338 & 1452 & 0.57 & 0.42 & 0.50 & 0.31 & 0.16 & 0.12 & 10.4 & 0.42 & 1.99 \\
\hline 26 & 156 & 319 & 1102 & 0.49 & 0.73 & 0.34 & 0.45 & 0.17 & 0.23 & 10.1 & 0.31 & - \\
\hline 27 & 250 & 437 & 1106 & 0.51 & 0.47 & 0.37 & 0.58 & - & 0.19 & - & - & - \\
\hline mean & 434 & 427 & 970 & 0.44 & 0.43 & 0.40 & 0.39 & 0.18 & 0.20 & 9.5 & 0.37 & 1.95 \\
\hline
\end{tabular}

TABLE 1: Technical constants for trabecular bone

Linear regression on the logarithmic data yielded

$$
\sigma_{c}=0.012 \mathrm{E}^{0.97} \quad(\mathrm{r}=0.94)
$$

This close relationship between strength and stiffness is practically a linear one, which implies an almost constant strain at failure regardless the wide variation in strength found in trabecular bone.

\subsection{Correlation between mechanical properties and density}

Linear regression between apparent density and each of the three elastic moduli resulted in

$$
\begin{aligned}
& E_{1}=6310^{2} \rho_{a}^{3.1} \quad(r=0.73) \quad E_{2}=19 \quad 10^{2} \rho_{a}^{1.7} \quad(r=0.83) \\
& \mathrm{E}_{3}=41 \quad 10^{2} \mathrm{p}_{\mathrm{a}}^{1.5} \quad(\mathrm{r}=0.82)
\end{aligned}
$$

A power relationship was chosen, although this did not yield better correlation coefficients than a first degree relationship between these parameters. Linear regression between apparent density and strength in proximal distal direction resulted in 


$$
\sigma_{c}=38 \rho_{\mathrm{a}}^{1.5} \quad(\mathrm{r}=0.88)
$$

Also in the case of strength the power relation model did not correlate stronger than the linear model. The results implie that density does not fully account for the wide variation in mechanical properties of trabecular bone.

4. A STRUCTURAL MODEL OF TRABECULAR BONE

A structural model enables the prediction of the global behaviour of the bone, knowing the behaviour of the individual trabeculae, i.e. it provides a relation between the macroscopic and the microscopic mechanical behaviour of the bone structure. An intramedullary fixed prostheses is cemented for a large part in a plate/rod type of trabecular bone. Therefore this structure has been chosen for the mechanical modelling.

The essential premise of the model is the assumption that the loads on the structure are transferred from one plate to another by means of the interconnecting rods. Fig. $2 a$ shows a 2-dimensional cross section of the structural model.

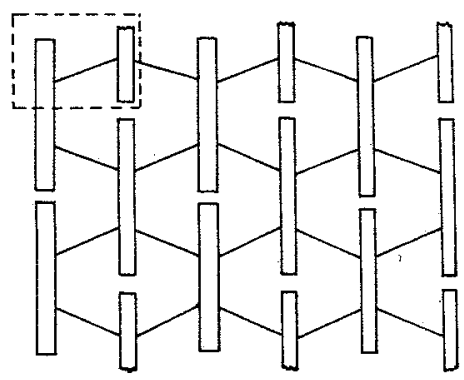

(a)

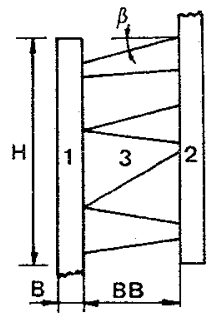

(b)

FIGURE 2: Two-dimensional cross section of the structural trabecular model

A simplification of the structure consists of the adoption of various symmetry planes. In this way, the mechanical behaviour of a small part of the model (shown in fig. $2 \mathrm{~b}$ ) characterizes the behaviour of the complete structure. Each interconnecting rod in fig. $2 \mathrm{a}$ in fact represents a system of rods as indicated in fig. $2 \mathrm{~b}$. The rods have various angles with respect to the parallel plates but are assumed to have some preferred orientation.

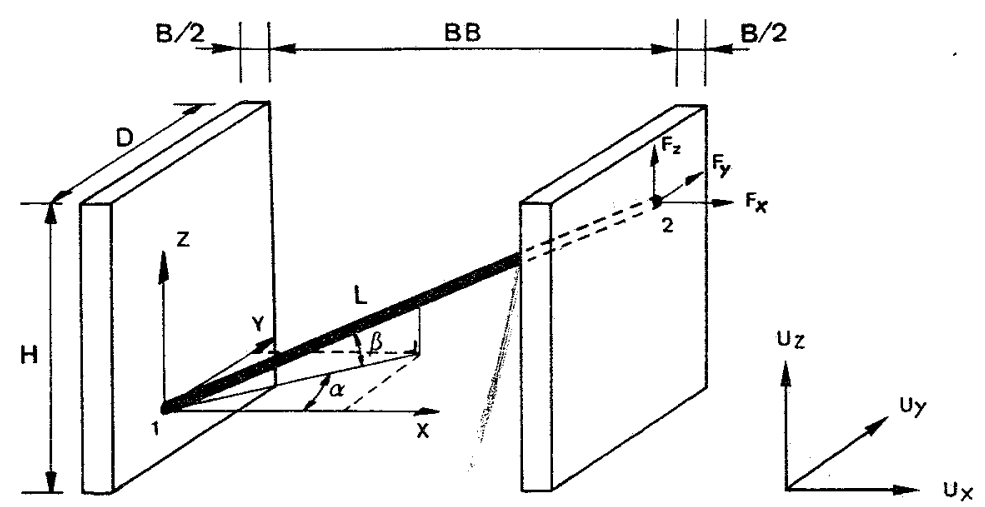

FIGURE 3: Characteristic part of the plate/rod model (only one rod is shown) 
An interconnecting cylindrical rod has length $L$, radius $R$, Young's modulus $E$ and is loaded at its ends by the parallel plates with forces and moments (see fig. 3). Beam theory is used to relate the force on the rod ends and the displacement difference between the rod ends. The plate transmits the resulting force of a finite number of rods and the direction $(\alpha, \beta)$ of the rods supposed to be characterized by a bivariate normal distribution $G$ with the mean angles $\alpha_{0}$ and $\beta_{0}$, standard deviations $\sigma_{\alpha}$ and $\sigma_{\beta}$ and correlation coefficient $p$.

$$
G=\frac{1}{2 \pi \sigma_{\alpha} \sigma_{\beta} \sqrt{1-p^{2}}} \exp \left\{\frac{-1}{2\left(1-\rho^{2}\right)}\left[\left(\frac{\alpha-\alpha_{0}}{\sigma_{\alpha}}\right)^{2}-2 p\left(\frac{\alpha-\alpha_{0}}{\sigma_{\alpha}}\right)\left(\frac{\beta-\beta_{0}}{\sigma_{\beta}}\right)+\left(\frac{\beta-\beta_{0}}{\sigma_{\beta}}\right)^{2}\right]\right\}
$$

The total force which is exerted on each plate by the rods then may be found by integrating over all possible angles $\alpha$ and $\beta$ (see for further details Klever (1984)). In this way a relation between the forces exerted on a plate and the displacements of that plate is obtained, which may be transformed in a relation between global stresses and strains by means of the dimensions of the model (B, BB, H, D) shown in fig. 3 . Thus a11 the orthotropic elastic constants are expressed as functions of the geometrical parameters $\mathrm{H}, \mathrm{D}, \mathrm{BB}, \mathrm{B}$ and $\mathrm{R}$, the Young's modulus $\mathrm{E}$ of the bone rods, the number of bone rods $\mathrm{N}$ and as functions of the bone rod angle distribution parameters $\alpha_{0}, \beta_{0}, \sigma_{\alpha}, \sigma_{\beta}$ and $\rho$.
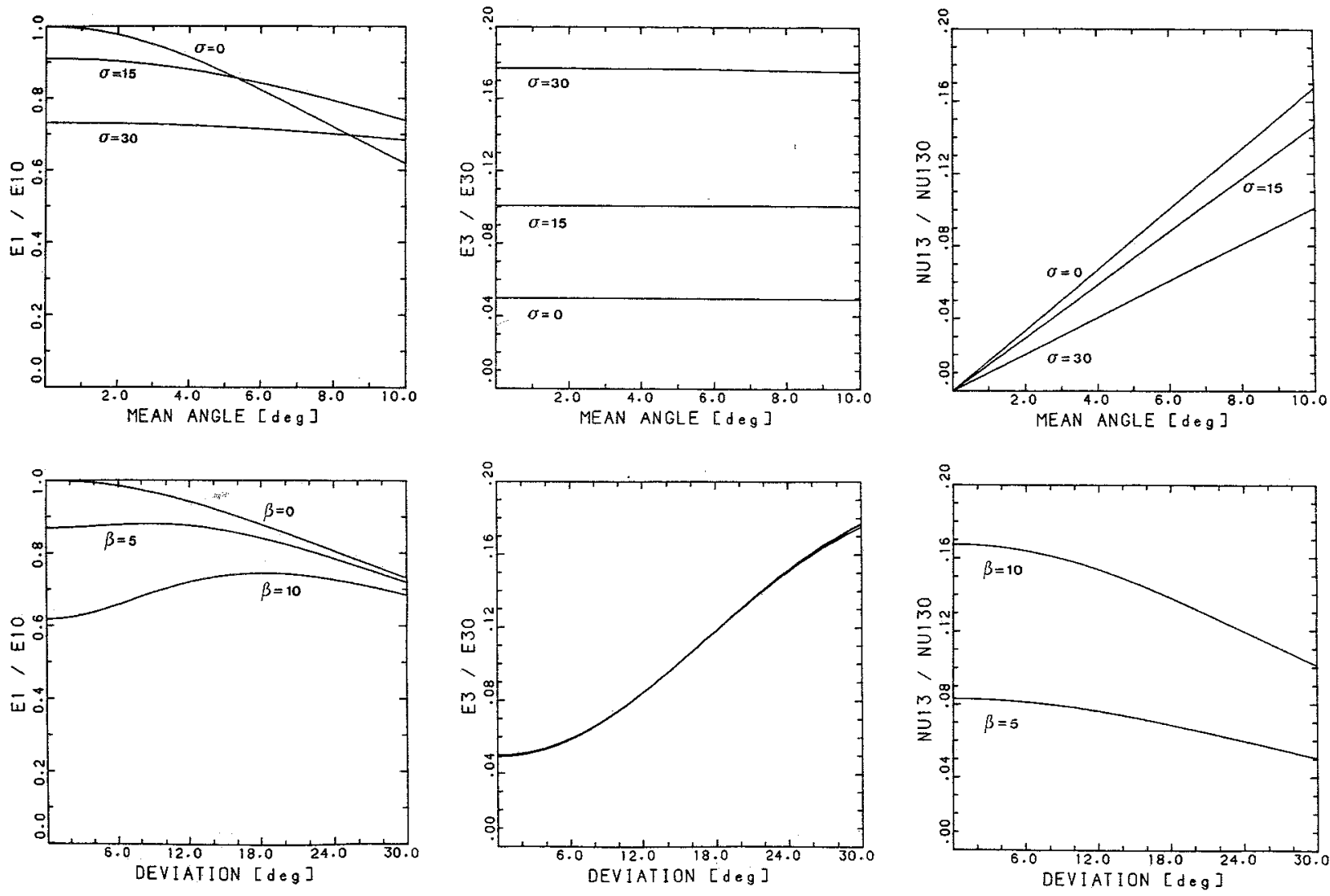

FIGURE 4: Dimensionless Young's moduli $\mathrm{E}_{\mathrm{x}}$ and $\mathrm{E}_{z}$ and Poissons ratio $\nu_{\mathrm{xz}}$ of the model as functions of the mean angle $\beta_{0}$ and the standard deviation $\sigma_{\beta}$ 
In this paper results will be presented for the case that all the bone rods lie in the $x-z$ plane, i.e. $\alpha_{0}=0$ and $\sigma_{\alpha}=0$. The Young's $\operatorname{moduli} E_{x}$ and $E_{z}$ and Poisson's ratio $\nu_{x z}$ are shown in fig. 4 as functions of the mean angle $\beta_{0}$ and the standard deviation $\sigma_{\beta}$.

The following dimensionless quantities are used:

$$
\frac{E_{1}}{E_{10}} \equiv \frac{E_{x} B B H D}{E N \pi R^{2}(B B+B)} \quad \frac{E_{3}}{E_{30}} \equiv \frac{E_{z} B B(B B+B) D}{E N \pi R^{2} H} \quad \frac{v_{13}}{v_{130}} \equiv v_{x z} \frac{B B+B}{H}
$$

As a result of the model the shear modulus $G_{z x}$ appears to be strongly related to the Young's modulus $E_{z}$ and for realistic parameters this relation is shown to be

$$
G_{z x} \approx\{(B B+B) / H\}^{2} \quad E_{z}
$$

The dimensionless modulus $E_{1} / E_{10}$ appears to be only moderately dependent on the mean angle $\beta_{0}$ and the standard deviation $\sigma_{\beta}$.

The modulus $E_{3} / E_{30}$ varies strongly with the deviation, but the mean angle does not play any role.

The Poisson's ratio $v_{13} / v_{130}$ is determined mainly by the mean angle (as could be expected), but also to some extent by the deviation. It should be noticed that $\nu_{z x}$ is a dependent quantity due to the symmetry requirements of the constitutive matrix and equals $\nu_{x z} E_{x} / E_{z} \cdot$

Within a realistic range of its parameters the trabecular bone model presented here describes a great variety of the anisotropic elastic material constants. For realistic model parameters these properties lie within the range of actually measured material constants of trabecular bone.

\section{REFERENCES}

[1] Carter, D.R. and Hayes, W.C. (1976),

Bone compressive strength: The influence of density and strain rate.

Science, Vol. 194, 1976, pp. 1174-1175.

[2] Goldstein, S.A., Wilson, D.L., Sonstegaard, D.A. and Matthews, L.S. (1983),

The mechanical properties of human tibial trabecular bone as a function of methaphyseal location.

J. Biomech., Vo1. 16, 1983, pp. 965-969.

[3] Knauss, P. (1981),

Material properties and strength behaviour of spongy bone tissue at the human coxal femur (in German).

Biomed. Techn., Vo1. 26, 1981, pp. 200-210.

14] Carter, D.R. and Hayes, W.C. (1977),

The compressive behaviour of bone as a two-phase porous structure.

J. Bone Jt. Surg., Vo1. 59-A, no. 7, 1977, pp. 954-962.

[5] Klever, F.J., (1984),

On the Mechanics of fallure of artificial knee joints.

Ph.D. Thesis, Twente University of Technology, Enschede, 1984, The Netherlands. 